\title{
ЛЕКСЕМА ДАХ: ЛІТЕРАТУРНА VS СЛЕНГОВА
}

У статті описано розвиток сленгових значень літературної лексеми “дах", здійснено аналіз дистрибуиійних семантичних моделей через оцінку колокачій коефічієнтом LogDice. У дослідженні комплексно застосовано корпуснокерований $і$ корпуснобазований підходи на основі використання найбільшого корпусу украӥнської мови - ГРАК, який має найповнішу мета-, морфо- й семантичну розмітку. Розвідка ьрунтується на ідеях дистрибутивної семантики, що описує зміни в значеннях через частотні характеристики дистрибуцій у корпусі.

Ключові слова: корпус, модель, лексема, фразеологічна одиниия (ФО), CQL.

Taran O., Lebedenko Yu. Lexeme ДАХ/ROOF: Standard vs Slang. The paper presents both corpus-based and corpus-driven approaches to the analysis of slang meanings development of the Ukrainian lexeme "dax / roof". It describes distributional semantic models of the above-mentioned lexeme through the estimation of collocations by the LogDice score.

The study is based on the idea of distributive semantics which deals with semantic changes due to the frequency of distributions in a corpus of texts. General Regionally Annotated Corpus of Ukrainian (GRAC) was taken as the data base because it is the largest Ukrainian corpus. It contains more than 728 million tokens (v. 11) and also has a linguistic annotation: morphological and semantic.

Analysis of distributional semantic models of the Ukrainian lexeme "dax / roof" revealed the regularity and frequency of the lexeme in collocations, which are possible only when slang meanings are implemented. Recognition of the lexeme "dax / roof" meaning occurs by identifying the distributional semantic model. The semantic structure of the lexeme "dax / roof" consists of 4 sememes: sememe-3 is phraseologically connected, and sememe-4 shows a constructive connection. Both of them are realized in slang units. The frequency of distributional semantic models of sememe-3 and sememe-4 testifies to such order of their definition though SUM-20 includes only one of them (sememe-4). Our study distinguished phraseological units which were not recorded in lexical or phraseological dictionaries. So, these units reflect synchronous language changes. The statistical score allows to assess the legitimacy of inclusion of some phraseological units into dictionaries.

Keywords: corpus, model, lexeme, phraseological unit, CQL. 


\section{Вступ}

Соціолекти поповнюються як зовнішніми запозиченнями, так і внутрішніми: $з$ інших соціолектів, діалектів, а також шляхом семантичної деривації літературних лексем. Останній спосіб творення сленгізмів поки не досліджений в українській соціолінгвістиці, що й зумовило наше звернення до цієї проблеми.

Оскільки будь-які семантичні зміни починаються зі слововживання і закріплюються в узусі під впливом частотності, релевантними для цього дослідження є ідеї дистрибутивної семантики (V. Kulkarni, B. Perozzi, R. Al-Rfou, \& S. Skiena; M. Rodda, \& A. Lenci; E. Sagi, S. Kaufmann, \& B. Clark; S. Hunston, G. Francis, \& Ch. Johnson; G. Lapesa, S. Evert, \& S. Schulte Im Walde), що описує зміни в значеннях через частотні характеристики дистрибуцій у корпусі. В українській соціолінгвістиці таке дослідження із застосуванням корпусних технологій здійснюється вперше.

\section{Методи дослідження}

Імпонує запропонована методика аналізу дистрибуційних семантичних моделей через оцінку колокацій коефіцієнтами Dice, loglikelihood, MI, t-score, z-score, здійснювана за допомогою програмного забезпечення, що дало змогу порівняти синтагматичні й парадигматичні відношення лексичних одиниць (Lapesa, Evert, \& Schulte Im Walde, 2014). Семантичні зміни, що відбуваються на синхронійному рівні, не завжди фіксовані тлумачними словниками, тож виявити їх дозволяє корпуснобазований (він є дедуктивним) або корпуснокерований (індуктивний) підходи. Ми застосовуватимемо їх комплексно, як це було запропоновано Д. Байбером (Biber, 2012), що дасть змогу виявляти явища як мови, так і мовлення, зокрема такі граматичні конструкції, що не описані граматичною теорією, проте регулярно з'являються в мовленні. Корпуснобазоване дослідження з погляду соціолінгвістики має такі переваги: охоплює не якийсь один соціолект, а мову загалом у всіх її варіантах, стилях і жанрах (Biber, 2012), а отже, уможливлює ідентифікацію одиниць загального сленгу. У цій розвідці залучаємо дані найбільшого корпусу української мови ГРАК, версія 11 (ГРАК, 2017-2021), що містить понад 728 млн токенів і має найповнішу мета-, морфо- й семантичну розмітку. У визначенні компонентного складу полісемантичної лексеми керуємося 
ідеями Л. Лисиченко про зв'язки лексичного значення слова й поняття, з яким воно співвіднесене (Лисиченко, 2008).

Мета цього дослідження - показати розвиток сленгових значень у літературної лексеми дах; завдання: 1) встановити обсяг значення шляхом аналізу лексикографічних фіксацій лексеми даx; 2) визначити реалізацію сленгових значень у дистрибуційних семантичних моделях зі статистичною оцінкою корпусних даних.

\section{Виклад основного матеріалу}

I. Лексема даx у загальномовних словниках. Лексема дах в українській мові є давнім запозиченням через польську (у ній ï̈ засвідчують з XV ст. (Рудницький, 1982: т. II: 12)) з німецької мови в значенні 'покрівля' (Мельничук, 1985: 15): ії фіксують у цьому самому значенні з XVI ст. (Рудницький, 1982: 12), зокрема «Лексикон» Памви Беринди (1627) (Іларіон, 1979: 322). Лексикографічні фіксації семантичних змін протягом останніх 100 років наводимо нижче в таблиці:

\begin{tabular}{|c|c|c|c|}
\hline Грінченко & СУМ-11 & ВТССУМ & СУМ-20 \\
\hline 1 ЛСВ & 2 ЛСВ & 2 ЛСВ & 3 ЛСВ \\
\hline $\begin{array}{l}\text { кровля, } \\
\text { криша } \\
\text { (Грінченко, } \\
\text { 1907: 359) }\end{array}$ & $\begin{array}{l}\text { 1) Верхня час- } \\
\text { тина будівлі, } \\
\text { що служить їі } \\
\text { покриттям; } \\
\text { покрівля; } \\
\text { 2) перен. Домівка, } \\
\text { житло (СУМ- } \\
\text { 11, 1970-1980, } \\
\text { т. 2: 214) }\end{array}$ & $\begin{array}{l}\text { 1) Верхня час- } \\
\text { тина будівлі, } \\
\text { що служить } \\
\text { ії покриттям; } \\
\text { покрівля; } \\
\text { 2) перен. До- } \\
\text { мівка, житло } \\
\text { (ВТССУМ, } \\
\text { 2005: 274) }\end{array}$ & $\begin{array}{l}\text { 1) Верхня частина будівлі, } \\
\text { споруди, що слугує її покрит- } \\
\text { тям; покрівля; } \\
\text { 2) перен. Домівка, житло } \\
\text { 3) жарг. Злочинне угрупування, } \\
\text { посадова особа, які на пев- } \\
\text { них умовах здійснюють } \\
\text { покровительство кому- } \\
\text { небудь (СУМ-20, 2015-2021). }\end{array}$ \\
\hline
\end{tabular}

СУМ-20 фіксує ще дві ФО: вальмовий дах (ЛСВ-1), під одним дахом (ЛСВ-2). Отже, бачимо різну поняттєву віднесеність прямого ЛСВ-1 і метонімічного ЛСВ-2 у СУМ-11, ВТССУМ, СУМ-20. Так само в СУМ-20 метафоричний ЛСВ-3, що є похідним від ЛСВ-1, має іншу поняттєву віднесеність та стилістичну маркованість (тут не вдаватимемося до дискусії про розмежування термінів “сленг” / “жаргон”, що в наукових і термінологічних джерелах часто $€$ взаємозамінні).

II. Лексема даx у сленгових словниках. Українські соціолектні словники XIX ст. не фіксують сленгізм даx - натомість виявляємо його в різних значеннях і навіть як омоніми в лексикографічних працях кінця XX - поч. XIX ст.: 
ЛІНГВІСТИЧНІ ДОСЛІДЖЕННЯ: зб. наук. праць ХНПУ імені Г. С. Сковороди. 2021. Вип. 54. Ч. ІІ

\begin{tabular}{|c|c|c|c|}
\hline Пиркало & Ставицька & Кондратюк & Аркушин \\
\hline 1 ЛСВ & 3 ЛСВ & 2 омоніми & 1 ЛСВ \\
\hline \multirow[t]{2}{*}{$\begin{array}{l}\text { Здоровий } \\
\text { глузд } \\
\text { (Пиркало, } \\
\text { 2002: 184) }\end{array}$} & \multirow{2}{*}{$\begin{array}{l}\text { 1) мол., жарт. Голова, мізки, здоровий } \\
\text { глузд; } \\
\text { 2) бізн., крим. Прикриття від рекету, } \\
\text { мафії; } \\
\text { 3) крим. Зв'язки у владних, бізнесових } \\
\text { та правоохоронних структурах } \\
\text { (Ставицька, 2005: 117) }\end{array}$} & $\begin{array}{l}\text { Психіка, розум, } \\
\text { здатність адек- } \\
\text { ватно сприймати } \\
\text { навколишній світ }\end{array}$ & \multirow[t]{2}{*}{$\begin{array}{l}\text { Голова } \\
\text { (Аркушин, } \\
\text { 2011: 70) }\end{array}$} \\
\hline & & $\begin{array}{l}\text { Протекція (Кон- } \\
\text { дратюк, 2006: 106) }\end{array}$ & \\
\hline
\end{tabular}

Як бачимо, фіксації відбивають такі два поняття: а) розум / психіка / здатність людини адекватно сприймати, тобто психофізична характеристика людини; б) кримінальне, владне покровительство бізнесу - це соціальна характеристика. 3 огляду на це вважаємо, що ЛСВ-3 в словнику Л. Ставицької $є$ відтінком значення, а не окремим значенням. Обидва значення мають метафоричний зв'язок із ЛСВ-1 літературної лексеми дах: а) за зовнішніми ознаками (те, що зверху, без чого будинок втрачає свої житлові функції); б) за функційною подібністю (прихисток від зовнішнього світу). Очевидно, вони розвинулися паралельно та за семантичною аналогією 3 російським арготизмом крыша, який як суржикізм функціонує в українському мовленні. Тож аналізовані сленгові значення розглядаємо як ЛСВ-3 і ЛСВ-4 лексеми дах. ЛСВ-3 виявляє фразеологічну зв'язаність, яку засвідчують соціолектні словники: дах тріщить; дах зриває, рве, підриває; дах повзе, їде; давити на дах (Кондратюк, 2006: 106), дах (криша / стріха) відітає, їе / поїхала; дах зірвало; поїхати дахом (мізками) (Ставицька, 2005: 117). Усе це дає підстави висунути гіпотезу про те, що реалізація ЛСВ-3 і ЛСВ-4 зумовлена певними контекстами, дистрибуційними семантичними моделями, а отже, ці значення $€$ конструктивно або фразеологічно зв’язаними. На користь цієї гіпотези свідчить такий помічений факт: «різні значення лексеми відрізняються типовими дистрибуціями в різних патернах» (Hunston, Francis, \& Johnson, 2000: 3).

\section{III. Лексема даx у корпусі ГРАК.}

Корпуснобазований підхід дає змогу перевірити висунуту гіпотезу. Оскільки сленгізми неприйнятні в наукових, релігійних і офіційно-ділових стилях, усі запити в ГРАК мали такі обмеження: $<$ doc(style="EGO"|style="FIC"|style="JOU"|style="SPO")/> Аналіз правих і лівих дистрибуцій лексеми дах (Н.в. або З.в.), імовірність їх сумісної 
появи в тексті оцінювали за допомогою показника LogDice (релевантним $€>1)$. Надалі у визначенні дистрибуційних моделей керувалися цією статистичною оцінкою колокацій (рис. 1).

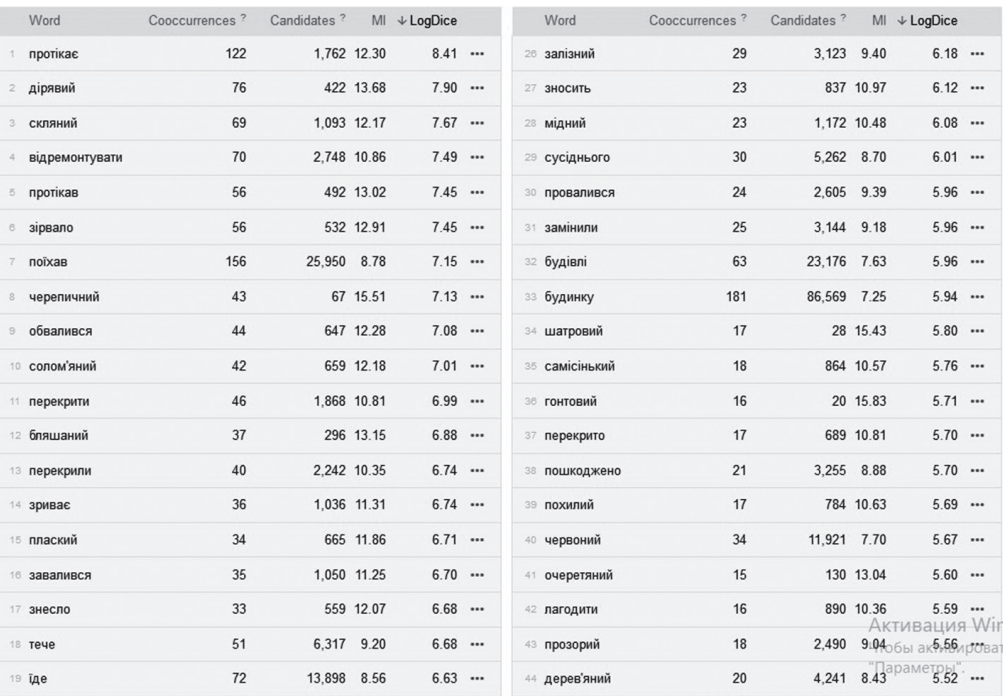

Рис. 1

Корпуснокерований підхід також дав змогу виявити 9 контекстів із ФО ЛСВ-1 вище даху - 'багато' (Та у них своїх проблем - вище даху! [Україна молода, 2015]); 693 вживання ФО ЛСВ-2 [мати (жукати, знайти, отримати, дати, втратити)/свій, власний] дах (дашок) над головою - ‘житло' ${ }^{2}$ що не зафіксовані тлумачними лексичними й фразеологічними словниками.

ЛСВ-3 реалізується в декількох дистрибуційних моделях.

1. Автоматизація пошуку фразеологічно зв'язаних значень моделі «дах (Н.в. одн.) + дієслово в пре-/постпозиції» утруднюється ії̈ омонімічністю з вільними словосполученнями, що реалізують номінативне значення (дах тече / падає / розвалюється / гниє тощо). CQL-запит (([word="дах"][tag="verb.*:s:3"|tag="verb.*:past:n"|tag="verb.*:inf"])| ([tag="verb.*:s:3"|tag="verb.*:past:n"|tag="verb.*:inf"][word="дах"])) within $<$ s/> виявив 175 реалізацій ЛСВ-3 з дієсловами в постпозиції та 217 в препозиції. Неодиничні наводимо в таблиці:

${ }^{2}$ ВТССУМ наводить словосполучення дах над головою як приклад реалізації ЛСВ-2, однак його частотність, регулярність появи саме в такій моделі та переносне значення, очевидно, свідчать про фразеологізацію вислову. 
ЛІНГВІСТИЧНІ ДОСЛІДЖЕННЯ: зб. наук. праць ХНПУ імені Г. С. Сковороди. 2021. Вип. 54. Ч. ІІ

\begin{tabular}{|c|c|c|c|}
\hline \multicolumn{2}{|c|}{ Дах + дієслово } & \multicolumn{2}{|c|}{ Дієслово + даx } \\
\hline $\begin{array}{c}\text { Леми (абсолютна } \\
\text { частота) }\end{array}$ & $\begin{array}{c}\text { Словоформи (абсо- } \\
\text { лютна частота) }\end{array}$ & $\begin{array}{c}\text { Леми (абсолютна } \\
\text { частота) }\end{array}$ & $\begin{array}{l}\text { Словоборми (абсо- } \\
\text { лютна частота) }\end{array}$ \\
\hline $\begin{array}{l}\text { їхати (40) /поїхати } \\
(95 / 4)\end{array}$ & $\begin{array}{l}\text { їде (40)/ поїде (17), } \\
\text { поїхав (78) }\end{array}$ & $\begin{array}{l}\text { їхати }(30 / 5) / \\
\text { поїхати }(79 / 10)\end{array}$ & $\begin{array}{l}\text { їде (30)/ поїде (5), } \\
\text { поїхав (74) }\end{array}$ \\
\hline $\begin{array}{l}\text { зривати (12) /зі- } \\
\text { рвати (13) }\end{array}$ & $\begin{array}{l}\text { зриває (9), зривало } \\
\text { (2) зриватиме (1) / } \\
\text { зірве (6), } \\
\text { зірвало (7) }\end{array}$ & $\begin{array}{l}\text { зривати }(23 / 2) \text { / } \\
\text { зірвати }(30 / 2)\end{array}$ & $\begin{array}{l}\text { зриває (23) / зірве } \\
\text { (3), зірвало (27) }\end{array}$ \\
\hline знести (7) & знесе (7) & знести $(10 / 2)$ & знесло (10) \\
\hline рвати (2) & рве (2), & з’їхати (7) & з'їхав (7) \\
\hline 3’їхати (2) & з’їе (2) & рвати $(11 / 2)$ & рве (6), рвало (5) \\
\hline & & підривати (4) & підриває (4) \\
\hline
\end{tabular}

Зазначені в словниках колокати тріщить, повзе, відлітає в корпусі не знайдено - очевидно, це оказіональні вживання. Наскрізний пошук виявлених дієслівних правих і лівих колокатів лексеми дах засвідчив нечастотні омонімічні сполучення, що реалізують пряме значення: дах падає, дах з'інджає, [буря] дах зриває, дах поӥхав, поїхав дах, [вітер, ииклон] зірве/зриває дах, [ураганом] зірвало дах, [вибухом] знесло дах - у них усіх лексема дах є або суб'єктом дії, або об'єктом. У сленгових же ФО дієслово завжди безособове, до того ж у цій моделі часто наявний суб'єкт, на який спрямована дія /стан (займенник або іменник на позначення особи). Така модель неможлива для реалізації прямих значень лексеми дах. У контексті «солом'яній хаті» зриває дах дієслово є безособовим, але суб'єкт - неістота. Крім цих моделей, виявлено також інфінітивні: як у ЛСВ-1 (може зірвати дах), так і ЛСВ-3 (у таблиці їхн частотність наведена через скісну в круглих дужках у стовпчику лем). Вони не зафіксовані словниками.

2. Розширений CQL-запит (([tag="verb.*"][word="дахом"]) |([word="дахом"] [tag="verb.*"]))within $<$ s/> показав, що моделі «поїхати+дахом» (15), «дахом+поїхати» (8) не мають варіативних дієслівних компонентів, реалізують тільки ЛСВ-3, є ФО, омонімічних вільних словосполучень не мають.

3. Так само перевіряємо варіативність дієслівного компонента моделі «давити+на+дах»: фразеологічно зв'язане значення ЛСВ-3 реалізується тільки в такому сполученні компонентів, у ГРАК фіксуємо одне знайдення: Відстань, яка поволі росте між друзями, завжди боляче давить на дах [А. Дністровий, 2002]. 
Аналіз колокатів лексеми даx 3 LogDice $>1$ дав змогу звузити пошук за певними типовими моделями, що реалізують ЛСВ-4: 1) «абстрактний (сленговий) прикметник + дах» (69 контекстів): потітичний (25), мент(i/o)вський (16/6), надійний (8), серйозний (4), депутатський (3), кримінальний (2), державний (2) - більшість прикметників не сполучається з лексемою дах у ЛСВ-1 і ЛСВ-2; 2) безприйменникові моделі з перехідним дієсловом: забезпечити / тримати/ шукати дах (3) - ЛСВ-1 не можуть реалізовувати; 3) прийменникові моделі: працювати під дахом (11); бути / жити без даху (5) - вони омонімічні моделям, які реалізують ЛСВ-2, але при цьому мають ще компонент “над головою” і є ФО.

\section{Висновки}

Аналіз дистрибуційних семантичних моделей лексеми дах на основі статистичної оцінки ії колокацій у корпусі ГРАК дав змогу виявити: 1) регулярність і частотність появи лексеми в сполученні з колокатами, що можливі тільки в реалізації сленгових значень; 2) розпізнавання значення лексеми дах відбувається шляхом ідентифікації дистрибуційної семантичної моделі; 3) ЛСВ-3 є фразеологічно зв'язаним, а ЛСВ-4 виявляє конструктивну зв'язаність, а отже, гіпотезу підтверджено; 4) частотні показники ЛСВ-3 й ЛСВ-4 засвідчують саме такий порядок їх визначення, хоча СУМ-20 містить тільки одне значення (ЛСВ-4); 5) не зафіксовані лексичними й фразеологічними словниками ФО, що відбивають синхронійні мовні зміни; 6) частотні показники також дають можливість оцінити правомірність включення до словникових статей ФО (вони мають бути зафіксовані щонайменше тричі в трьох різних джерелах).

Перспективою дослідження семантичного розвитку лексеми дах $€$ опис її епідигматичних відношень.

\section{ЛІТЕРАТУРА}

1. Лисиченко, Л. А. (2008). Багатозначність у лексико-семантичній системі: структурний, семантичний, когнітивний аспекти. Харків: Основа. 2. Biber, D. (2012). Corpus-Based and Corpus-driven Analyses of Language Variation and Use. In Heine, B., \& Narrog, H. (Ed.). The Oxford Handbook of Linguistic Analysis. DOI: 10.1093/oxf ordhb/9780199544004.013.0008. 3. Hunston, S., Francis, G., \& Johnson, Ch. (2000). Pattern Grammar: A Corpus-driven Approach to the Lexical Grammar of English. Amsterdam Philadelphia: John Benjamins Publishing Company. DOI: 10.1016/S0346-251X(02)00025-8. 4. Lapesa, G., Evert, S., \& Schulte Im Walde, S. (2014). Contrasting Syntagmatic and Paradigmatic Relations: Insights from Distributional Semantic Models. In Proceedings 
of the Third Joint Conference on Lexical and Computational Semantics (p. 160-170). Dublin, Ireland. DOI: 10.3115/v1/S14-1020.

\section{ДЖЕРЕЛА}

5. Аркушин, Г.Л. (2011). Словник луцьких жаргонізмів і сленгізмів. Луцьк: Волин. нац. ун-т ім. Лесі Українки. 6. ВТССУМ - Бусел, В. Т. (2005). Великий тлумачний словник сучасної украӥнської мови. Київ; Ірпінь: Перун. 7. ГРАК - Шведова, М., Вальденфельс, Р. фон, Яригін, С., Рисін, А., \& Старко, В. та ін. (2017-2021). Генеральний регіонально анотований корпус украӥнської мови (ГРАК). Київ, Львів, Єна. Узято з uacorpus.org. 8. Грінченко, Б. Д. (1907). Словарь украинскаго языка. (Т. 1). Київ. 9. Іларіон, Митрополит (1979). Етимологічно-семантичний словник украӥнської мови. (Т. I). Вінніпег: Накладом тов. «Волинь». 10. Кондратюк, Т. М. (2006). Словник сучасного украӥнського сленгу. Харків: Фоліо. 11. Мельничук, О. С. (Ред.) (1985). Етимологічний словник української мови. (Т. 2). Київ: Наук. думка. 12. Пиркало, С. (2002). Словник українського молодіжного сленгу. В Пиркало С. Зелена Маргарита (с. 155-284). Київ: Джерела М. 13. Рудницький, Я. Б. (1982). Етимологічний словник украйнської мови. (Т. ІІ). Вінніпег: Укр. вільна Акад. наук. 14. Ставицька, Л. (2005) Украйнський жарлон. Київ: Критика. 15. СУМ-11 - Білодід, І. К. (Ред.) (1970-1980). Словник украӥнської мови. (Т. 1-11). Київ: Наук. думка. Узято 3 http://sum.in.ua. 16. СУМ-20 - Словник украӥнської мови. (2015-2021). (Т. 1-20). Узято з http://lcorp.ulif. org.ua/ExplS/.

\section{REFERENCES}

1. Lysychenko, L.A. (2008). Bahatoznachnist u leksyko-semantychnii systemi: strukturnyi, semantychnyi, kohnityvnyi aspekty [Polysemy in the lexical-semantic system: structural, semantic, cognitive aspects]. Kharkiv: Osnova [in Ukrainian]. 2. Biber, D. (2012). Corpus-Based and Corpus-driven Analyses of Language Variation and Use. In Heine, B., \& Narrog, H. (Ed.). The Oxford Handbook of Linguistic Analysis. DOI: 10.1093/oxfordhb/9780199544004.013.0008 [in English]. 3. Hunston, S., Francis, G., \& Johnson, Ch. (2000). Pattern Grammar: A Corpus-driven Approach to the Lexical Grammar of English. Amsterdam - Philadelphia: John Benjamins Publishing Company. DOI: 10.1016/S0346251X(02)00025-8 [in English]. 4. Lapesa, G., Evert, S., \& Schulte Im Walde, S. (2014). Contrasting Syntagmatic and Paradigmatic Relations: Insights from Distributional Semantic Models. In Proceedings of the Third Joint Conference on Lexical and Computational Semantics (pp. 160-170). Dublin, Ireland. DOI: 10.3115/v1/S14-1020 [in English].

\section{SOURCES}

5. Arkushyn, H.L. (2011). Slovnyk lutskykh zharhonizmiv i slenhizmiv [Dictionary of Lutsk Jargon and Slang Units]. Lutsk: Volyn. nats. un-t im. Lesi Ukrainky [in Ukrainian]. 6. VTSSUM - Busel, V.T. (2005). Velykyi tlumachnyi slovnyk suchasnoi ukrainskoi movy [Large Dictionary of Modern Ukrainian]. Kyiv; Irpin: Perun [in Ukrainian]. 7. GRAC Shvedova, M., Fon Valdenfels, R., Yaryhin, S., Rysin, A., \& Starko, V. et al. (2017-2021). Heneralnyi rehionalno anotovanyi korpus ukrainskoi movy (HRAK) [General Regionally Annotated Corpus of Ukrainian (GRAC)]. Kyiv, Lviv, Yena. Retrieved from uacorpus.org [in Ukrainian]. 8. Hrinchenko, B. D. (1907). Slovar' ukrainskago yazyka [A Dictionary of the Ukrainian Language]. (V. 1). Kyiv [in Ukrainian]. 9. Ilarion, Mytropolyt (1979). Etymolohichno-semantychnyi slovnyk ukrainskoi movy [Etymological and Semantic Dictionary of the Ukrainian Language]. (V. I). Vinnipeg: Nakladom tov. «Volyn» 
[in Ukrainian]. 10. Kondratiuk, T. M. (2006). Slovnyk suchasnoho ukrainskoho slenhu [Modern Ukrainian Slang Dictionary]. Kharkiv: Folio [in Ukrainian]. 11. Melnychuk, O. S. (Ed.) (1985). Etymolohichnyi slovnyk ukrainskoi movy [Etymological Dictionary of the Ukrainian Language]. (V. 2). Kyiv: Nauk. dumka [in Ukrainian]. 12. Pyrkalo, S. (2002). Slovnyk ukrainskoho molodizhnoho slenhu [Dictionary of Ukrainian Youth Slang]. In Pyrkalo, S. Zelena Marharyta [Green Margarita] (pp. 155-284). Kyiv: Dzherela M [in Ukrainian]. 13. Rudnytskyi, Ya. B. (1982). Etymolohichnyi slovnyk ukrainskoi movy [Etymological Dictionary of the Ukrainian Language]. (V. II). Vinnipeg: Ukr. vilna Akad. nauk [in Ukrainian]. 14. Stavytska, L. (2005). Ukrainskyi zhargon [Ukrainian Jargon Dictionary]. Kyiv: Krytyka [in Ukrainian]. 15. SUM-11 - Bilodid, I. K. (Ed.) (1970-1980). Slovnyk ukrainskoi movy [Dictionary of the Ukrainian Language]. (V. 1-11). Kyiv: Nauk. dumka. Retrieved from http://sum.in.ua [in Ukrainian]. 16. SUM-20 - Slovnyk ukrainskoi movy [A Dictionary of the Ukrainian Language]. (2015-2021). (V. 1-20). Retrieved from http://lcorp.ulif.org.ua/ExplS/ [in Ukrainian].

Таран Оксана Сергіївна - кандидат філологічних наук, доцент, доцент кафедри прикладної лінгвістики, Національний університет «Львівська політехніка»; вул. С. Бандери, 12, м. Львів, 79013, Україна.

Tel.: +38-032-25-82-138

E-mail: oksana.s.taran@lpnu.ua

http://orcid.org/0000-0001-6312-9563

Taran Oksana Sergiivna - Candidate of Philological Sciences (Ph.D.), Docent, Associate Professor at the Department of Applied Linguistics, Lviv Polytechnic National University; 12 S. Bandery Str., Lviv, 79013, Ukraine.

Лебеденко Юлія Миколаївна - кандидат філологічних наук, доцент, доцент кафедри української мови, Харківський національний педагогічний університет імені Г. С. Сковороди; вул. Валентинівська, 2, м. Харків, 61168, Україна.

Tel.: +38(097) 9287080

E-mail: lebedenkoj2015@gmail.com

http://orcid.org/0000-0002-1291-3742

Lebedenko Yuliia Mykolaivna - Candidate of Philological Sciences (Ph.D.), Docent, Associate Professor at the Department of Ukrainian language, H. S. Skovoroda Kharkiv National Pedagogical University; 2 Valentynivska Str., Kharkiv, 61168, Ukraine.

Надійшла до редакції 27 березня 2021 року

\section{CITATION}

ДСТУ 8302:2015: Таран О. С., Лебеденко Ю. М. Лексема дах: літературна vs сленгова. Лінгвістичні дослідження: зб. наук. пр. Харк. нац. пед. ун-ту імені Г. С. Сковороди. Харків, 2021. Вип. 54. Ч. II. С. 153-161. DOI: https://doi.org/10.34142/23127546.2021. 54.2.14

APA: Таран, О. С., \& Лебеденко, Ю. М. (2021). Лексема дах: літературна vs сленгова. Лінгвістичні дослідження, 54 (II), 153-161. DOI: https://doi.org/10.34142/ 23127546.2021.54.2.14 